\title{
EXAMINATION OF THE RELATIONSHIP BETWEEN PHYSICAL ACTIVITY LEVELS AND LIFE QUALITIES OF TEACHERS WHO TEACH IN SECONDARY EDUCATION INSTITUTIONS
}

\author{
Kerim Rüzgar1, \\ Nurettin Konar ${ }^{2 i}$ \\ İnönü University, \\ Health Sciences Institute, \\ Malatya, Turkey \\ 2Department of Physical Education and Sport, \\ Bandırma 17 Eylul University, \\ Balıkkesir, Turkey
}

\begin{abstract}
:
Aim of this research is to compare the relationship between the physical activity levels and quality of life of teachers working in secondary education institutions. A total of 331 secondary school teachers, including 205 men and 126 women from various branches, participated in our study in Batman province and secondary education institutions. The teachers who participated in the research were descriptive such as gender, age range, branch, chronic disease, and what if this disease was present. "International Physical Activity Questionnaire Short Form" for determining information and physical activity levels and "Nottingham Health Profile" questionnaires were applied for their quality of life. The statistical analysis of the data was done by using SPSS 20.0 program, and nonparametric tests such as Kruskal-Wallis, Mann Whitney U Test and Spearman Cholera test were used because the data were not normally distributed. $6.6 \%$ of secondary education teachers who participated in the study had a chronic illness, physical activity level according to gender, quality of life according to age groups, physical skill level of special talent teacher compared to other branch teacher and significant differences in quality of life $(p<0.05)$. There were no significant differences in other parameters and in the relationship between physical activity level and life satisfaction ( $p>0.05)$. As a result of the research, it has been concluded that the level of physical activity affects the level of physical activity of the gender and special education teachers and the other branch teachers, the quality of life is affected by the age group, and there is no significant relationship between the level of secondary school teachers' physical activity.
\end{abstract}

Keywords: quality of life, physical activity level, secondary education, teacher

${ }^{i}$ Correspondence: email kerimruzgar0@gmail.com, nurettinkonar@gmail.com 


\section{Introduction}

This study was conducted to investigate the association between the physical activity level and the life qualities of teachers who works at the secondary schools in Batman province. For a healthy life, sports is defined as the physical actions including recreational activities and dance, and skeletal muscles' energy comsumption through body movements (Miles, 2007).

This definition includes all body movements from free time activities, all sports branches, daily actions to walking, running and riding a bike (Miles, 2007). Physical activities have a vital role in guarding and improving our health both mentally and physically (World Health Organization, 2002).

Physical activity (PA), takes also an important place in improving our life qualities (Gümüş et al., 2017). At the top ranks of the factors determining the life quality, health condition of the person, PA level, family structure, financial situation, level of education etc. take place (Uzuner, 2016).

Undoubtedly, health has a special importance among these factors. For centuries, research has been carried out to make individuals healthier, delay aging, and stay energetic and positive. It is desired to live a healthy and long life, which we have control of, such as increasing the quality of life, being resistant to negative situations, living in a healthy environment, proper nutrition and being active (Özüdoğru, 2013).

Recently, encouraging and empowering PA policies have been pursued in order to improve quality of life by especially World Health Organization (WHO) (Tekkanat, 2008). It is supposed that in numerous modern societies, sedentary life has become a pattern and many are doing their daily shopping through virtual markets sitting at the computer, which induces serious health problems (Bek, 2008).

We, as a country, need to attach the necessary importance to education in order to survive in this rapidly developing and changing world, maintain a healthy and quality life and to make PA a lifestyle. Undeniably, teachers are one of the most important pillars of our educational system. In order to keep up with the requirements of the age, it is extremely important that our teachers have the necessary equipment and knowledge and be ready both mentally and physically. In order for the teacher to be beneficial to the society, besides having a high level of professional knowledge, it is necessary to be a contemporary person with good morals who is interested in art and sports. The teacher has duties such as being a model for the student and guiding them in reaching the information. At the same time, the teacher must comply with the society's "teacher" perception with his/her lifestyle, clothing, talks, interests and human relations (Açıkgöz, 2005). In order for a quality and good education process to take place, there is a need for teachers who are well-trained in every subject, who are not indifferent to current conditions and technological developments, and who are always open to development (Seferoğlu, 2004). Teachers' interests, attitudes, behaviours, needs and values comprise their personal traits. In recent studies, it has been demonstrated that these traits have an extreme influence on the students. Considering how valuable the roles of teachers are, 
especially in developing countries, it would be appropriate to emphasize the importance of teachers (Küçükahmet, 1994).

With the developing technology, people do less PA, but sit more. Today, due to the development of computer games, individuals at all levels of society have entered a less active period (Brady, 1998). People need to make PA a lifestyle and stay away from a sedentary life in order to have a healthier life. Along with paying attention to our nutrition and rest, we can lead a lively and fit life thanks to the continuity of PA. In the researches, the idea that the moderate and high level of FA reduces some types of cancer and the risk of death was defended (Miller et al, 1994). Considering all these, it can be easily seen how important FA is and how it affects all segments of the society. For a healthy life, exercise should be an integral part of our daily life. PA and exercise improve quality of life, prolong it, and help us achieve mental health (Çetin, 2010).

\section{Method}

\subsection{Research Model}

In this research, general survey model and descriptive statistics model, which are types of the descriptive research methods, were used. The survey model is known as a research approach that aims to explain an existing situation as it exists (Karasar, 2005).

\subsection{Research Sample}

The sample of our research consists of 2263 teachers working in secondary schools in Batman province. The sampling of our research is randomly selected 205 male and 126 female teachers working in different branches ( Arts, Chemistry, Physical Education and Sports, Biology, Physics, Geography, Information Technologies, Child Development, Religious Culture and Moral Knowledge, Turkish Language and Literature, Philosophy, English, Mathematics, Special Education, Psychological Counseling and Guidance, Music, History) and a total of 331 secondary education institutions participated in the study. Of the teachers participated in the study, 145 are between the ages of 20-30, 147 are between the ages of 31-40, 34 are between the ages of $41-50$ and 5 are 50 years old and over.

\subsection{Data Colection Tool}

For the descriptive information such as gender, age range, branch, chronic disease, if any, what this disease is, and the determination of physical activity levels, the "International Physical Activity Questionnaire Short Form" and for evaluation of the quality of life, the "Nottingham Health Profile" questionnaires were applied to the teachers participating in our research.

\subsubsection{International Physical Activity Questionnaire Short Form}

The international validity and reliability of the questionnaire was evaluated by Craig et al. In 2003, its validity and reliability in our country was made by Karaca and Turnagöl 
in 2007. The questionnaire consists of 7 questions and 4 parts. Part 1 contains two questions and the duration of vigorous physical activity that individuals have done within 7 days, part 2 contains two questions and the duration of moderate physical activity that individuals have done within 7 days, part 3 contains two questions and the duration of walking done by the individuals within 7 days and the 4th part consists of a question and the time individuals spend sitting in 7 days (Karaca, Turnagöl 2007). The evaluation of the Questionnaire was made as;

Physical Activity Level $=$ Number of Days x Activity Level Coefficient (MET).

The intense physical activity coefficient is $8 \mathrm{METs}$, the moderate intensity physical activity level coefficient is 4 METs, the walking coefficient is 3.3 METs, and the sitting coefficient is 1 MET.

\subsubsection{Nottingham Health profile}

It is one of the questionnaires used to determine the quality of life. The questionnaire consists of 7 sub-dimensions and has a total of 45 items. The Pain Sub-Factor consists of 8 questions, the Emotional Reactions Factor consists of 9 questions, the Sleep Sub-Factor consists of 5 questions, the Social Isolation Sub-Factor consists of 5 questions, the Physical Activity Sub-Factor consists of 8 questions, the Energy Sub-Factor consists of 3 questions, and the Part 2 Sub-Factor consists of 7 questions. The questions are formed in double Likert type(Yes/No). . If the participants answer no to each question, they get 0 points, and if they answer yes, they get different points for each question (Küçükdeveci et al. 2000). A maximum of 607 points and a minimum of 0 points can be obtained in the questionnaire. A high score indicates that the individual's quality of life is at a low level, while a low score indicates that the individual's quality of life is at a high level.

\subsection{Data Analysis}

SPSS 20.0 Package Program, which is one of the statistical programs, was used in the analysis of the findings obtained from the research. Teachers' gender, age group, branch, chronic disease status were evaluated as frequency and percentage. Physical activity levels and quality of life of teachers in secondary education institutions participating in the research were analyzed according to gender, age group, chronic disease status, special education branch teacher and other teachers, teachers in the field of social sciences and teachers in the field of science and lastly the relationship between the PA level and the life quality were evaluated.

Before starting the analysis of the data, a normality test was performed, and since the data were not normally distributed, non-parametric tests such as Kruskal-Wallis, Mann Whitney U Test and Spearman Correlation test were used. 


\section{Findings}

Table 1 shows that $61.9 \%$ ( $\mathrm{f}=205)$ of the teachers participating in the research are male, $38.1 \%(\mathrm{f}=126)$ were women, $43.8 \%(\mathrm{f}=145)$ of the teachers participating in the study were between the ages of $20-30,44.4 \%(f=147)$ were between the ages of $31-40,10.3 \%$ ' $(f=34)$ were between the ages of $41-50$ and $1.5 \%(f=5)$ were aged 50 and over. When the branch distribution of the teachers participating in the research is examined, it is seen that teachers from 17 different branches participated in the research, $12.4 \%(\mathrm{f}=41)$ of these branches were physical education and sports teachers, $12.7 \%(\mathrm{f}=42)$ Turkish language and literature, 9.4\% ( $\mathrm{f}=31)$ Mathematics teachers and at least $0.9 \%(\mathrm{f}=3)$ special education teachers, $(0.9 \%)$ Turkish teachers and 1.2\% ( $\mathrm{f}=4)$ Informatics and Ttechnology teachers took place in the study.

Table 1: Demographic Characteristics of Teachers Working in Secondary Education Institutions Participating in the Research

\begin{tabular}{|c|c|c|c|}
\hline & & $\mathbf{f}$ & $\%$ \\
\hline \multirow[t]{3}{*}{ Gender } & Male & 205 & 61.9 \\
\hline & Female & 126 & 38.1 \\
\hline & Total & 331 & 100 \\
\hline \multirow[t]{5}{*}{ Age Group } & 20-30 Age & 145 & 43.8 \\
\hline & 31-40 Age & 147 & 44.4 \\
\hline & 41-50 Age & 34 & 10.3 \\
\hline & $50+$ Age & 5 & 1.5 \\
\hline & Total & 331 & 100 \\
\hline \multirow[t]{18}{*}{ Branch } & Physical Education & 41 & 12.4 \\
\hline & Information Technologies & 4 & 1.2 \\
\hline & Biology & 23 & 6.9 \\
\hline & Geography & 14 & 4.2 \\
\hline & Child Development & 7 & 2.1 \\
\hline & Religious Culture and Moral Knowledge & 23 & 6.9 \\
\hline & Turkish Language and Literature & 42 & 12.7 \\
\hline & Philosophy & 16 & 4.8 \\
\hline & Physics & 19 & 5.7 \\
\hline & Arts & 19 & 5.7 \\
\hline & English & 16 & 4.8 \\
\hline & Chemistry & 19 & 5.7 \\
\hline & Math & 31 & 9.4 \\
\hline & Music & 11 & 3.3 \\
\hline & Special Education & 3 & 9 \\
\hline & Psychological Counseling and Guidance & 17 & 5.1 \\
\hline & History & 23 & 6.9 \\
\hline & Total & 331 & 100 \\
\hline
\end{tabular}

Table 2 shows that $93.4 \%(\mathrm{f}=309)$ of secondary school teachers do not have a chronic disease, and $6.6 \%(\mathrm{f}=22)$ have a chronic disease. 
When we look at the distribution of teachers with chronic diseases, $27.3 \%(\mathrm{f}=6)$ have asthma, $18.2 \%(\mathrm{f}=4)$ diabetes, $13.6 \%(\mathrm{f}=3)$ sleep apnea, $9.1 \%(\mathrm{f}=2)$ inflammatory disease. Rheumatism, $4.6 \%(\mathrm{f}=1)$ bronchitis, $4.6 \%(\mathrm{f}=1)$ hepatitis, $4.6 \%(\mathrm{f}=1)$ hernia, allergy, $4.6 \%(\mathrm{f}=1)$ kidney failure, $4.6 \%(\mathrm{f}=1)$ had pharyngitis and it is seen that $4.6 \%(\mathrm{f}=1)$ have Mediterranean fever.

Table 2: Distribution of Teachers Working in Secondary Education Institutions Participating in the Research by Chronic Disease Status

\begin{tabular}{|l|l|c|c|}
\hline \multirow{2}{*}{ Do you have any chronic disease? } & & $\mathbf{f}$ & $\mathbf{\%}$ \\
\hline \multirow{5}{*}{ If yes, what are they? } & Yes & 22 & 6.6 \\
\cline { 2 - 4 } & No & 309 & 93.4 \\
\cline { 2 - 4 } & Total & 331 & 100 \\
\hline & Asthma & 6 & 27.3 \\
\cline { 2 - 4 } & Diabetes & 4 & 18.2 \\
\cline { 2 - 4 } & Bronchitis & 1 & 4.6 \\
\cline { 2 - 4 } & Sleep Apnea & 3 & 13.6 \\
\cline { 2 - 4 } & Hepatitis & 1 & 4.6 \\
\cline { 2 - 4 } & Hernia of the Loins & 1 & 4.6 \\
\cline { 2 - 4 } & Allergy & 1 & 4.6 \\
\cline { 2 - 4 } & Renal Insufficiency & 1 & 4.6 \\
\cline { 2 - 4 } & Pharyngitis & 1 & 4.6 \\
\cline { 2 - 4 } & Inflammatory Rheumatism & 2 & 9.1 \\
\cline { 2 - 4 } & Mediterranean Fever & 1 & 4.6 \\
\cline { 2 - 4 } & Total & 22 & 100 \\
\hline
\end{tabular}

Table 3: Comparison of Physical Activity Levels and Quality ofLife of Teachers Working in Secondary Education Institutions Participating in the Research by Gender

\begin{tabular}{|l|l|c|c|c|c|c|}
\hline & Gender & $\mathbf{N}$ & $\mathbf{X}$ & $\mathbf{S S}$ & $\mathbf{Z}$ & $\mathbf{P}$ \\
\hline \multirow{2}{*}{$\begin{array}{l}\text { Physical Activity } \\
\text { Grand Total (MET) }\end{array}$} & Male & 205 & 2146.56 & 2013.38 & \multirow{2}{*}{-2.594} & \multirow{2}{*}{.009} \\
\cline { 2 - 7 } $\begin{array}{l}\text { Quality of Life } \\
\text { Grand Total }\end{array}$ & Female & 126 & 1706.76 & 1754.33 & & \\
\cline { 2 - 6 } & Male & 205 & 74.81 & 93.93 & \multirow{2}{*}{-1.902} & \multirow{2}{*}{.057} \\
\cline { 2 - 6 }
\end{tabular}

$\mathrm{P}<0.05$

In Table 3, physical activity levels and life quality of secondary school teachers by gender were compared. A significant difference was found in physical activity levels by gender $(p<0.05)$. According to this difference, it is seen that the physical activity levels of male teachers are higher than female teachers.

No significant difference was observed in terms of quality of life by gender $(p>0.05)$. Although there is no difference, we can say that the quality of life of male teachers is better than that of female teachers.

In Table 4, physical activity levels and quality of life of teachers working in secondary education institutions were compared according to age groups. Significant differences were found in the quality of life according to age groups $(\mathrm{p}<0.05)$. As a result of the post-hoc analysis carried out to determine the difference in the quality of life, it 
was seen that the difference was between the ages of 20-30 and 50+, and accordingly, the quality of life of the teachers aged 50+ who participated in the research was higher than the teachers aged 20-30.

Table 4: Comparison of Physical Activity Levels and Quality of Life of Teachers

Working in Secondary Education Institutions Participating in the Research by Age Groups

\begin{tabular}{|c|c|c|c|c|c|c|c|}
\hline & & $\mathbf{N}$ & $X$ & SS & KW & $\mathbf{P}$ & $\begin{array}{c}\text { Groups Showing } \\
\text { Difference }\end{array}$ \\
\hline \multirow{5}{*}{$\begin{array}{l}\text { Physical Activity } \\
\text { Grand Total (MET) }\end{array}$} & 20-30 Age & 145 & 2029.0 & 1705.98 & \multirow{4}{*}{4.124} & \multirow{4}{*}{.248} & \multirow{4}{*}{-} \\
\hline & 31-40 Age & 147 & 1924.9 & 2081.42 & & & \\
\hline & 41-50 Age & 34 & 2046.4 & 2260.90 & & & \\
\hline & $50+$ Age & 5 & 1668.5 & 1121.70 & & & \\
\hline & Total & 331 & 1979.1 & 1928.07 & & & \\
\hline \multirow{5}{*}{$\begin{array}{l}\text { Quality of Life } \\
\text { Grand Total }\end{array}$} & 20-30 Age & 145 & 97.58 & 103.26 & \multirow{4}{*}{8.825} & \multirow{4}{*}{.038} & \multirow{4}{*}{$\begin{array}{c}20-30 \\
\text { age }>\text { 50Age }+\end{array}$} \\
\hline & 31-40 Age & 147 & 74.17 & 90.96 & & & \\
\hline & 41-50 Age & 34 & 67.55 & 95.56 & & & \\
\hline & $50+$ Age & 5 & 22.36 & 29.58 & & & \\
\hline & Total & 331 & 82.96 & 97.19 & & & \\
\hline
\end{tabular}

$\mathrm{P}<0.05$

When the physical activity levels by age groups were examined, no significant difference was observed. Although there is no difference, the group with the highest level of physical activity is 40-50 years old ( $X=2046.41)$, while the group with the lowest level of physical activity is aged 50 and over $(X=1668.50)$.

Table 5: Comparison of Physical Activity Levels and Quality of Life of Teachers Working in Secondary Education Institutions Participating in the Study by Chronic Disease Status

\begin{tabular}{|c|c|c|c|c|c|c|}
\hline & & $\mathbf{N}$ & $X$ & SS & $\mathrm{Z}$ & $\mathbf{P}$ \\
\hline \multirow{2}{*}{$\begin{array}{l}\text { Physical Activity } \\
\text { Grand Total (MET) }\end{array}$} & Yes & 22 & 2593.67 & 2936.95 & \multirow{2}{*}{,- 681} & \multirow{2}{*}{.496} \\
\hline & No & 309 & 1935.39 & 1834.66 & & \\
\hline \multirow{2}{*}{$\begin{array}{l}\text { Quality of Life } \\
\text { Grand Total }\end{array}$} & Yes & 22 & 104.85 & 95.84 & \multirow{2}{*}{-1.913} & \multirow{2}{*}{.056} \\
\hline & No & 309 & 81.41 & 97.25 & & \\
\hline
\end{tabular}

$\mathrm{P}<0.05$

In Table 5, physical activity levels and quality of life of teachers working in secondary education institutions were compared in consideration of their chronic disease status. There was no significant difference in the quality of life of teachers according to their chronic disease status ( $p>0.05$ ). Although there is no difference, it is seen that the quality of life of teachers without chronic disease is better than teachers with chronic disease.

There was no significant difference in physical activity levels of teachers according to their chronic disease status ( $\mathrm{p}>0.05)$. Although there is no difference, we can say that the physical activity levels of teachers with chronic diseases are better than those who do not.

In Table 6, no significant difference was found in the physical activity levels of teachers working in secondary education institutions according to their status as teachers 
of social sciences and science branches $(\mathrm{p}>0.05)$. Although there is no difference, we can say that the physical activity levels of the teachers in the field of social sciences are better than the branch teachers in the field of science.

Table 6: Comparison of Physical Activity Levels and Quality of Life of Social Sciences and Science Teachers Participating in the Study

\begin{tabular}{|l|l|c|c|c|c|c|}
\hline & & $\mathbf{N}$ & $\mathbf{X}$ & $\mathbf{S S}$ & $\mathbf{Z}$ & $\mathbf{P}$ \\
\hline \multirow{2}{*}{$\begin{array}{l}\text { Physical Activity } \\
\text { Grand Total (MET) }\end{array}$} & Social Sciences & 239 & 1985.47 & 1868.55 & & \\
\cline { 2 - 7 } Quality of Life & Science & 92 & 1962.69 & 2085.42 & -.462 & .644 \\
Grand Total & Social Sciences & 239 & 85.91 & 100.21 & -.698 & .485 \\
\cline { 2 - 6 } & Science & 92 & 75.30 & 88.92 & & \\
\hline
\end{tabular}

$\mathrm{P}<0,05$

When the quality of life of the teachers in secondary education institutions is examined according to their status as teachers of social sciences and branches of science, no significant difference was observed $(\mathrm{p}>0.05)$. Although there is no difference, we can say that the quality of life of the teachers in the fields of science is better than the teachers in the field of social sciences.

Table 7: The Relationship between Physical Activity Levels and Quality of Life of Teachers Working in Secondary Education Institutions Participating in the Research

\begin{tabular}{|c|c|c|c|}
\hline & & $\begin{array}{l}\text { Physical Activity } \\
\text { Grand Total (MET) }\end{array}$ & $\begin{array}{c}\text { Quality of Life } \\
\text { Grand Total }\end{array}$ \\
\hline \multirow{3}{*}{$\begin{array}{l}\text { Physical Activity } \\
\text { Grand Total (MET) }\end{array}$} & $\mathrm{r}$ & 1 & -.054 \\
\hline & $\mathrm{P}$ & & .327 \\
\hline & $\mathrm{N}$ & 331 & 331 \\
\hline \multirow{3}{*}{$\begin{array}{l}\text { Quality of Life } \\
\text { Grand Total }\end{array}$} & $\mathrm{r}$ & -.054 & 1 \\
\hline & $\mathrm{P}$ & .327 & \\
\hline & $\mathrm{N}$ & 331 & 331 \\
\hline
\end{tabular}

$\mathrm{P}<0.05$

When the relationship between physical activity levels and quality of life of teachers working in secondary education institutions participating in the research is examined in Table 7, it is seen that there is a negative and weak relationship between physical activity level and quality of life. This level of relationship was not found to be significant $(p>0.05)$.

\section{Discussion and Result}

A total of 215 administrative personnel, 144 women and 71 men, participated in the study in which Özmumcu researched "The Effect of Eating Awareness and Physical Activities on Quality of Life of Administrative Staff of a University Hospital in Isparta Province". While no significant difference was found in the physical activity levels of the administrative staff according to age groups and chronic disease status in the study $(p>0.05)$, significant differences were found in the physical activity levels according to the 
genders $(p<0.05)$. In our study, a significant difference was found with regard to the gender, but no significant difference was found in relation to the age group and chronic disease status. These findings support our findings (Özmumcu, 2019).

A total of 442 nurses, 61 men and 381 women, participated in Kılınç's master's thesis study in 2018. According to the research findings, while significant differences were found in physical activity levels according to age groups and gender factor $(\mathrm{p}<0.05)$, no significant differences were found in physical activity levels according to chronic disease status $(\mathrm{p}>0.05)$. While significant differences were observed in our study in terms of the gender factor, no significant differences were observed in physical activity levels in terms of chronic disease status and age groups. Gender and chronic disease factors in this study support our findings (Kılınç, 2018).

80 female and 20 male, in total 100, parents participated in Y1ldiz's study in which he examined the relationship between the quality of life and physical activity levels of parents with autistic children. In his study, a significant difference was found in physical activity levels according to the gender variable. According to this difference, it was stated that the physical activity levels of men $(X=2748.67 \pm 3975.63 \mathrm{MET})$ were higher than that of women $(X=1231.63 \pm 1285.76 \mathrm{MET})$. No correlation was found between age and physical activity level $(p<0.05)$. These findings support our findings (Y1ld1z, 2019).

As a result, in consequence of the research, it was concluded that the physical activity level was affected by gender and being a special education teacher and being a teacher of other branches; similarly, the quality of life was affected by age group, and on the other hand there was no significant relationship between physical activity level of teachers working in secondary education institutions and quality of life.

\subsection{Suggestions}

As a result of our research, the following suggestions can be made;

- The research sample can be expanded.

- Comparisons can be made with teachers working in other provinces or other educational levels.

- There were 22 people with chronic diseases in our study. By reaching more teachers with chronic diseases, better results can be achieved.

- Physical activity level and quality of life can be investigated with respect to different characteristics such as marital status, work place, province, district, etc.

- In our study, no relationship was found between the physical activity level of teachers working in secondary education institutions and their quality of life. The reason for this can be investigated.

\section{Conflict of Interest Statement}

The authors declare no conflicts of interests. 


\section{About the Authors}

Kerim Rüzgar, İnonu University, Health Science İnstitute, Research interests: Education and Exercise for Disabled People. orcid.org/0000-0002-8482-8176.

Prof. Nurettin Konar, Department of Physical Education and Sport, Turgut Ozal University, Battalgazi, Malatya. Research interests: Education and Exercise for Disabled People. orcid.org/0000-0002-2542-7524.

\section{References}

Açıkgöz KÜ. Etkili Öğrenme ve Öğretme. Ankara, Eğitim Dünyası Yayınları, 2005

Bek N. Sağlık Bakanlı̆̆ı. Fiziksel Aktivite ve Sağlığımız. Ankara: Klasmat Matbaacılık, 2008.

Brady F, The physical activites throughout the lifespan: Implications for counselors and teachers, By: Journal of Humanistic Education-Development 1998, 36: 4-19

Çetin L. Sınıf Öğretmenlerinde Yaşam Kalitesi ve Etkileyen Bazı Faktörler. Sağlık Bilimleri Enstitüsü, Hemşirelik Programı, Yüksek Lisans Tezi, Sivas: Cumhuriyet Üniversitesi, 2010.

Gümüş H, Özgür S, Karakılıç M. Fiziksel aktivite için park ve rekreasyon alanlarına gelen kullanıcıların mekân seçimini ve fiziksel aktiviteye katılımın etkileyen faktörler. SPORMETRE Beden Eğitimi ve Spor Bilimleri Dergisi, 2017, 15 (1): 31-8.

Karaca A, Turnagöl HH. Çalışan bireylerde üç farklı fiziksel aktivite anketinin güvenirliği ve geçerliği. Spor Bilimleri Dergisi Hacettepe J. of Sport Sciences 2007. Karasar, N., Bilimsel Araştırma Yöntemleri, Nobel Yayınları. Ankara, 2005.

Kılınç F. Hemşirelerde Fiziksel Aktivite Düzeyi ile Yaşam Kalitesi Arasındaki İlişkinin Değerlendirilmesi. Sağlık Bilimleri Enstitüsü. Hemşirelik Anabilim Dalı. Yüksek Lisans Tezi, Gaziantep: Hasan Kalyoncu Üniversitesi, 2018.

Küçükahmet L. Öğretim İlke ve Yöntemleri. Gazi Büro Kitabevi, 5.Baskı, Ankara, 1994. Kücükdeveci AA, McKenna SP, Kutlay S, Gürsel Y, Whalley D, Arasil T. The development and psychometric assessment of the Turkish version of the Nottingham Health Profile. International Journal of Rehabilitation Research 2000, 23(1): 31-8.

Miles L. Physical and health, Nutrition Bulletin, 2007, 32:314-63.

Miller DJ, Freedson PS, Klime GM. Comparison of activity levels using the caltrac, accelerometer and five questionnaires med. Sci. in Sport and Exercises 1994, 26 (3): 376-382.

Özmumcu SB. Isparta İli Bir Üniversite Hastanesi İdari Personeli Yeme Farkındalığı ve Fiziksel Aktivitelerinin Yaşam Kalitesine Etkisi. Sağlık Bilimleri Enstitüsü, Halk Sağlığı Anabilim Dalı. Yüksek Lisans Tezi, Isparta: Süleyman Demirel Üniversitesi, 2019.

Özüdoğru E. Üniversite Personelinin Fiziksel Aktivite Düzeyi ile Yaşam Kalitesi Arasındaki İlişkinin İncelenmesi. Eğitim Bilimleri Enstitüsü, Beden Eğitimi ve 
Spor Anabilim Dalı. Yüksek Lisans Tezi, Burdur: Mehmet Akif Ersoy Üniversitesi, 2013.

Seferoğlu SS. Öğretmen adaylarının öğretmenliğe yönelik tutumları. XII. Eğitim Bilimleri Kongresi Bildiriler Kitab1, 2004, 42:413-3.

Tekkanat Ç. Öğretmenlik Bölümünde Okuyan Öğrencilerde Yaşam Kalitesi ve Fiziksel Aktivite Düzeyleri. Sağlık Bilimleri Enstitüsü, Sporda Psikososyal Alanlar Anabilim Dalı, Yüksek Lisans Tezi, Denizli: Pamukkale Üniversitesi, 2008.

Uzuner ME. Serebral Palsililerde Aquaterapinin İnce-Kaba Motor Becerilerine ve Yaşam Kalitelerine Etkisi. Sağlık Bilimleri Enstitüsü, Beden Eğitimi ve Spor Anabilim Dalı. Yüksek Lisans Tezi, Kocaeli: Kocaeli Üniversitesi, 2016.

Yıldız U. Otizmli Bireye Sahip Olan Ebeveynlerin Yaşam Kalitesi ve Fiziksel Aktivite Düzeyleri Arasındaki İlişkinin İncelenmesi. Lisansüstü Eğitim Enstitüsü, Sağlık Eğitimi Anabilim Dalı. Yüksek Lisans Tezi, Sakarya: Sakarya Uygulamalı Bilimler Üniversitesi, 2019.

World Health Organization, Physical in activity - a leading cause of disease and disability, warns WHO. http://www.who.int/topics/physical activity /en/WHO. (2002). Geneva, Switzerland: Erişim. 14 Kasım 2010. 

be applied to their work. Under the terms of this license, no permission is required from the author(s) or publisher for members of the community to copy, distribute, transmit or adapt the article content, providing a proper, prominent and unambiguous attribution to the authors in a manner that makes clear that the materials are being reused under permission of a Creative Commons License. Views, opinions and conclusions expressed in this research article are views, opinions and conclusions of the author(s). Open Access Publishing Group and European Journal of Physical Education and Sport Science shall not be responsible or answerable for any loss, damage or liability caused in relation to/arising out of conflict of interests, copyright violations and inappropriate or inaccurate use of any kind content related or integrated on the research work. All the published works are meeting the Open Access Publishing requirements and can be freely accessed, shared, modified, distributed and used in educational, commercial and non-commercial purposes under a Creative Commons attribution 4.0 International License (CC BY 4.0). 